\title{
UNDERSTANDING HOW CHANGE HAPPENS
}

\section{THE FACTORS THAT ACCOMPANY HEALING IN A WOUNDED SOCIAL STRUCTURE}

As a young man with radical ideas, the poet Pushkin considered himself fortunate not to have been caught up in the Decembrist Revolution. Later, Pushkin saw a prophetic role for literature that works, not in the Decembrists' revolutionary way, by confrontation, but through a gradual cultural transformation. The following passage occurs in Pushkin's short novel Kapitanskaya Dochka (The Captain's Daughter; Pushkin, 1954 [1836], p. 66, translation slightly adapted):

Young man, if these lines of mine ever fall into your hands, remember that the best and most enduring of changes are those which proceed from an improvement in morals and customs, and not from violent upheavals.

Pushkin's contemporary, Shelley, did not follow his friend Byron to war. Instead, he devoted the last year of his short life to his Defence of Poetry (discussed in Chapter 1) and his Philosophical View of Reform. Shelley did not rule out 'insurrection' as a last resort. His goal, however, was to develop a strategy of gradual change through non-violence. Gandhi would quote Shelley's (2003c) 'Mask of Anarchy' at public meetings. 
W.B.Yeats, in his poem 'To a Shade', compares the statesman Parnell to Sir Hugh Lane, who wanted to establish a gallery of impressionist paintings in Dublin (Yeats, 1994). The gallery project is seen by Yeats as an investment in future generations' receptiveness to ideas - their 'loftier thought' and 'sweeter emotion'. These terms echo the chuvstva dobroie ('nobler feelings') in a poem in which Pushkin (2008, p. 123) compares the reception of his own work within Russian society, and its transformative effect, to the impact of the Alexander Column that had recently been unveiled in front of the Winter Palace. Yeats intended the revival of Irish culture through the Abbey Theatre to accompany a political awakening, exactly as Pushkin or Shelley would have recommended.

In the last paragraph of Crime and Punishment, Dostoevsky (2000) refers to 'a man's gradual rebirth, his gradual crossing from one world to another, his acquaintance with a new, as yet unknown reality'. Our third axiom, that we should identify and explore the factors that accompany healing in a wounded social structure, proceeds from the poets' vision of how benign change happens. We can translate Dostoevsky's conception of a gradual crossing from one world to another to the domain of society and civilisation. The factors that accompany healing in a wounded social structure can then be identified and understood.

Crime and Punishment 'teaches reality and justice' in the face of 'revolutionary frenzy' (to borrow phrases from Yeats's 1923 Nobel lecture, 'The Bounty of Sweden'). The story unfolds in the slums of St Petersburg in the burning July heat. We encounter hellish living conditions, the near impossibility of ordinary family life. One of the main consequences of extreme poverty is prostitution. Throughout the novel, we learn a great deal about wages, rents, and prices, and how these affect the lives of the characters: not even Ulysses has as much detailed information on the cost of living as Crime and Punishment.

The names of the main characters in Crime and Punishment tell us a great deal about Dostoevsky's vision of non-violent social change. 'Raskolnikov' comes from a verb associated with splitting wood and also with breakaway movements in the Church - unpleasant associations. Raskolnikov's good and loyal friend is Razumikhin, suggesting 'razum', meaning reason and intellect. The prostitute whose heart becomes a 'fountain of life' for Raskolnikov is Sonya; the full form of her name is Sofya, from the Greek 'Sophia', which 
is the biblical term for the 'divine wisdom'. The drama of the novel - divisiveness and violence versus the transformative power of reason and charity - is summarised in the play of names.

Two aspects of Raskolnikov's character are of particular interest in the light of the approach we take in this book. The first is the absence in his life of a father figure or any other form of benign authority. Raskolnikov lost his father at a young age - just as Prince Myshkin, the 'idiot', is an orphan, there are fatherless young men in Demons, and the father of the Karamazov brothers had abdicated the role of parent. Sonya loves her father; but he, Marmeladov, is completely unable to provide for his children. Dostoevsky's main characters have no one to look up to and trust; broken family structures are mirrored by the pitilessness of economic and political structures.

Second, in the character of Raskolnikov, a key 19th-century political idea is examined close-up: that the 'great' man needs to set aside the 'ordinary' man's understanding of morality. The proposition that some agents are above ordinary morality contributed to what actually happened in Soviet Russia. The dream of a perfect society to be achieved by a small, ruthless avant-garde brought about a murderous dictatorship whose victims are counted in the millions.

What is less well understood is that Dostoevsky foresaw not only the risk of totalitarianism but also a threat to the increasingly open and secular societies that he knew from his travels in Western Europe. At the beginning of Crime and Punishment, Raskolnikov believes, or almost believes, that a successful human being is someone who overcomes his inhibitions and relies on skill to play the great role that he imagines for himself. A 'technocratic paradigm' (to borrow a phrase from Pope Francis) begins to shape an ethical vision - and this, according to Dostoevsky, underlies the danger faced by both Russia and Western Europe.

Raskolnikov's 'gradual crossing from one world to another' begins with his encounter with Sonya. Sonya's relationship with Raskolnikov unfolds through time according to an unpredictable pattern. In the end, Raskolnikov expresses his love for Sonya through the gesture of falling at her feet. He cannot find words for what is happening. The stages by which healing occurs do not lend themselves to exact measurement.

The believer Sonya intuits what is good in Raskolnikov, though she cannot follow his thinking; while Raskolnikov, not a believer, 
comes to respect and value the religious aspect of Sonya's life. Dostoevsky wrote four major novels on his return to St Petersburg from prison and exile - Crime and Punishment, The Idiot, Demons (or The Possessed), and The Brothers Karamazov. Together, the novels explore the intersection of politics and religion with life as lived and experienced. Does the relationship between Sonya and Raskolnikov hint at how the respectful engagement of public authorities with religious belief can bring new energy to the global conversation? A crucial aspect of the relationship between Raskolnikov and Sonya is that it is real and fruitful, though difficult to define. Previously, Raskolnikov was in the opposite situation. His clear and original ideas led to a brilliant article for the Periodical Review; in practice, he misjudged his own deepest instincts. Raskolnikov and Sonya together discover hope.

In the light of Dostoevsky's conception of a gradual crossing from one world to another, we attempt in what follows to describe the anatomy of benign social change - the factors that accompany healing in a wounded social structure.

\section{A COMPOSITION WITH TEN PANELS}

Our argument in relation to these principles or indicators of benign change does not follow a forensic logic. We look on the ten themes pursued below as panels in a broad composition, like a chapel by Giotto, Signorelli, or Michelozzo in which separate images are interrelated and mutually supportive. In this composition, the reader is invited into a 'conversation'. Whether for him or her there is an emerging, convincing pattern depends on a continuing process of reflection. 'Viewers' of this chapter are invited to add brighter colours to our images or to enlarge our 'composition' with new panels.

We assert that effective, non-violent action in the service of justice is marked, by and large, by the following characteristics:

1. mercy

2. dharma, decorum, religious reverence

3. respect for nature

4. the virtue of hesitation

5. humility as the primordial human value

6. gratuitousness and generosity 
7. knowledge of the particular situation combined with a vision of the whole

8. gradualness

9. finding unity in the presence of difference

10. constructive engagement with the holders of power

What all these ten themes have in common is that embracing them requires a certain style of imagination - call it the religious, literary, or historical imagination. We can acquire a deeper perspective on the nature of social change and therefore on the efficacy of different forms of political and diplomatic action.

\section{MERCY}

None of our factors of benign change involves action based primarily on self-interest or technical proficiency. On the contrary, they are more like dimensions of Shakespeare's quality of mercy:

The quality of mercy is not strained;

It droppeth as the gentle rain from heaven

Upon the place beneath. It is twice blest;

It blesseth him that gives and him that takes...

It is enthronèd in the hearts of kings,

It is an attribute to God himself.

(Merchant of Venice, Act 4, Scene 1, lines 190-196)

Shakespeare is in no doubt that mercy as a political value arises from the religious perspective:

we do pray for mercy;

And that same prayer doth teach us all to render

The deeds of mercy.

Psalm 85 (Vulgate 84) is a prayer for peace:

Mercy and Truth have come together, Justice and Peace have embraced.

Truth raised its arms from the earth, And Justice bent down from heaven.

The image of truth raising its arms and justice bending down from heaven suggests a child and its parents. The children in this picture, that is, human beings, should respect truth and practise mercy. 
Hebrew words such as hesed ('loving kindness and equity') and tsedakah ('justice-with-mercy') imply that our judgement of a situation is not even true or accurate in the absence of a saving or protective instinct that works in favour of the vulnerable.

\section{DHARMA, DECORUM, RELIGIOUS REVERENCE}

The great world civilisations have cherished a perspective in which decorum, tolerance, and religious reverence act as a check on personal self-aggrandisement, especially by rulers. In ancient China, the observance of rites and rituals ( $l i)$ is a key to the good of society. Laws and magistracies are for the benefit of the people, not the rulers. This benign dispensation is under the protection of Heaven: 'The people are of supreme importance; the altars to the gods of earth and grain come next; last comes the ruler' (Mencius 7B.14, quoted by Chan, 2014, p. 29).

In Ashoka's Rock Edicts, dharma, a way of life in conformity with truth, is a new and unifying concept. The shared social meaning promoted by Ashoka respects religion while not imposing a single religious doctrine. To live in accordance with dharma implies religious literacy and a moral disposition to respect limits.

Even in late 5th-century Athens, with traditional Greek religion under challenge, the first clause of the most important peace treaty of the era (the Peace of Nikias) reads as follows (Thucydides, 1996, V.18):

With regard to the Panhellenic temples, everyone who wishes, according to the customs of his country, to sacrifice in them, to travel to them, to consult the oracles, or to attend the games, shall be guaranteed security in doing so, both by sea and by land.

This concern with sanctuaries and rituals implies the presence of a pre-political culture, and also that a religious outlook disposes us to obey social rules for reasons that go beyond self-interest. In the Funeral Oration, Pericles praises the obedience of his fellow citizens to 'unwritten law' (Thucydides, 1996, II.37.3).

'Wonders are many and none more wonderful than man', proclaims the chorus in the central ode of Sophocles' Antigone. This hymn to human potential ends with an affirmation of the part played by the 'laws of the earth' and religious reverence in enabling 
humanity to flourish (Antigone, pp. 368-370): 'When we respect the laws of the earth and the sworn justice of the gods, ${ }^{1}$ the polis is exalted.'

Explaining her stand, Antigone invokes the same concept as Pericles: the "unwritten laws (agrapta nomima) whose life is not of today and yesterday but forever' (Antigone, pp. 454-457).

\section{RESPECT FOR NATURE}

The following are short excerpts from Ecclesiasticus 43:

The sun, as he emerges, proclaims at his rising 'A thing of wonder is the work of the Most-High!'

Great is the Lord who made him ...

The beauty of the heavens, the glory of the stars,

The Lord's glittering world so far above!

They take position according to his words and his decision ...

See the rainbow and praise its maker ...

Ice forms,

And water puts it on like a breastplate ...

Many things even greater than these are hidden,

For we have seen only a few of his works.

In a religious perspective, there is more to nature and the world than what we measure scientifically. There is a depth, a purpose, and a beauty that is not ours to give or take away. 'There lives the dearest freshness deep down things', writes the poet Gerard Manley Hopkins (2005, p. 1166) in 'God's Grandeur': the world is good and deserves from us the response of wonder. The Shinto religion in Japan is based on a reverence for nature.

To accept, even as a working hypothesis, that the earth and its creatures are in some sense 'given' or sacred, has ethical implications going beyond the sense of decorum or reverence that disposes us to live under laws. In the first instance, a sense of the 'given-ness' of life can have a particular impact on our approach to environmental questions:

It is impossible to see any way out of this crisis without an acceptance of limits and limitations, and this in turn, is, I think, intimately related to the idea of the sacred, however one may wish to conceive of it.

(Ghosh, 2016, p. 215) 


\section{THE VIRTUE OF HESITATION}

'Religious reverence' is relevant in many other sets of circumstances. Our spontaneous wonder or shame or anger in the face of gross facts is often more affecting than acute legal reasoning in preparing us for the work of justice. 'Cruel and unusual punishment', a criterion based on a personal sense of measure, is forbidden under law. Similarly, the concept of 'reasonable accommodation', again depending on our sense of measure, is used in many situations, for example, to ensure equal rights to persons with disabilities.

Socrates spoke of the intervention of his daimonion, a spirit not of his own making that holds him back from certain courses of action. In Thucydides, a far-seeing hesitation (mellesis promēthēs) is a centrally important value closely related to divine law (theios nomos), religious reverence (eusebeia), the sacred (to hosion), and the shared laws that offer hope to all (koinoi nomoi). ${ }^{2}$

The disastrous Sicilian Expedition is central to the structure of Thucydides' history. In the debate at Athens, the 'far-seeing hesitation' of which Nikias is capable is overruled by the Assembly. The daimonion of Socrates prompts a value judgement that coincides exactly on this particular point with the thinking of Nikias and Thucydides (Plutarch, Life of Nikias, XIII.6): 'Socrates' daimonion indicated plainly that the expedition would make for the ruin of Athens.'

Today, dealing with emerging issues in such fields as AI, biophysics, and new weaponry (cyber; lethal autonomous weapons systems), we may lose our way if we rely only on discursive reasoning. There are circumstances in which the sheer 'enormity' of what is proposed, the abandonment of a human scale, should give us pause.

The Greek virtue of hesitation, or compunction, partly anticipates the Heuristik der Furcht ('heuristics of fear') developed in the 20 th century by Hans Jonas. For Jonas, an appropriate hesitation in exploiting technology accompanies a heightened sense of planetary awareness. There should be no disconnect between individual moral choices and the sustainability of life on the planet (Jonas, 1984).

\section{HUMILITY AS THE PRIMORDIAL HUMAN VALUE}

We (most of us) sense that humility should govern our approach to nature. The world around us is the extraordinary result of billions of 
years of evolution. What does it mean to destroy some of its most beautiful features in the equivalent of an instant? To appreciate the enormity of what is happening is to begin to acquire humility. By humility, we also mean the question of Jesus (Matthew 7:4): 'How can you say to your brother, "Brother, let me take the speck out of your eye," when you yourself fail to see the plank in your own eye?" To the degree that we are willing to examine our current assumptions, we will embrace a humbler and more 'dialogical' approach to international relations.

Do we have the humility to hope? To accept that something new and better can happen in history, even when we ourselves do not see the full picture? The shepherds in St Luke's Gospel exemplify political humility. Moses and David are shepherds. Greek and Roman poets portray themselves as shepherds or goatherds. In their closeness to the natural world, their cooperative work patterns, their love of song, their sense of fairness, and their openness to new things, the shepherds of ancient literature embody the best of 'indigenous' culture; they represent, before we can put it into words, the religious, ethical, and political literacy that lies at the heart of our objectives in putting together this book.

An important dimension to 'religious reverence' and humility as political values is the light they shed on the relationship between act and consequence.

We read in Psalm 127 (Vulgate 126), verse 1:

Unless the Lord builds the house,

Those who build it labour in vain;

Unless the Lord watches over the city,

The watchman stays awake in vain.

Psalm 85 (Vulgate 84), quoted earlier on, calls on us to raise our arms like children to ask for justice. The Psalm continues (verse 12):

The Lord bestows happiness

As the soil gives its harvest.

In these passages, peace is an after-phenomenon, a gift from God. The Psalms give us an explicitly religious perspective on history; but even in the eyes of secular historians and political scientists, it is often difficult to prove a direct causal connection between one event and another. 
Military theorists sometimes explain the use of force as a way of 'sending a message'. However, the broader the geographical canvas and the longer the historical time scale, the harder it becomes to establish how and where the message has been received or to assess 'proportionality'. In the course of events, multiple short-term and long-term factors mingle with ordinary human fallibility. Some 'messages' turn events in unexpected directions. In his account of the slide to war in July 1914, the British historian Christopher Clark (2013, p. 555) states, '[A] profound sundering of ethical and political perspectives eroded consensus and sapped trust'.

As in systems theory, there is always a bigger picture in politics; often there is a feedback loop through which the source of change is itself transformed along the way. Military action is among the least precise of instruments. It can sow the seeds of future chaos; by a ricochet effect, it can impact negatively on the clear-sightedness of the doer.

The virtue of hope, to which we turn later, belongs in the space of uncertainty that separates our actions from their outcome; and in the space between our seeming powerlessness and our strong sense of what is right. 'We treat, God heals' - this insight in Ayurveda is often applicable in a political situation.

\section{GRATUITOUSNESS AND GENEROSITY}

The T'ang poet Bai Juyi (or 'Po-Chü-I') is celebrated for his sense of social justice and for the tension he experiences between his role as a high official and his love of everyday things. To find release, Bai Juyi puts the 'confusion' of the capital and the competition for 'fame' and 'profit' as far out of his mind as possible. In the autumn of 816, when in his 40s, Bai Juyi builds a chapel for himself and his friends high on a mountainside close by a Buddhist temple (Levy, 1971, pp. 54-55, slightly adapted):

How shall I wash my ears?

With the falling stream flying above my roof.

How shall I wash my eyes?

With white lotuses ...

In my left hand, I hold a single jug, 
In my right hand grasp a five-stringed lute ...

Drunk on desire, I look to heaven and sing ...

A man of the fields

Mistakenly drawn into the net of the world

Returns to the mountains,

A weary bird returns to thick foliage,

A deadened fish comes back to the clear stream.

Here is a passage from Seneca, the Stoic philosopher who served for many years as the Emperor Nero's principal political advisor (1935, De Beneficiis I.1.9):

the immortal gods, though some men neglect them or are irreligious, continue to shower their benefits upon us; for they act according to their divine nature and help all alike, even those who fail to understand their generosity.

Seneca questions whether we can explain a close and trusting relationship between doctor and patient in terms of the size of the doctor's fee. If the gods give us their benefits freely, it follows, for Seneca, that we too must give freely.

Here is a passage from Al-Insan, the 76th chapter of the Quran:

And they give food, despite their love of it, to the needy, and the orphan and the prisoner. 'We feed you only for the sake of God. We do not desire any reward from you, nor any thanks.'

Bai Juyi, with his interest in Buddhism; Seneca, as a Stoic; and of course the Quran, all have a religious perspective. However, as regards gratuitousness as a personal and political value, there is perhaps no clear borderline between the best of religious and the best of philosophical thought. In Chapter 3, we discussed Aristotle's thesis that our pursuit of a common project tends as a matter of experience to turn into friendship (philia) and ways of interacting that are no longer selfishly calculating. The culminating insight of Aristotle's ethics is that we pursue virtue for its own sake, and 'happiness comes afterwards' (epiginomenon ti). Aristotle's word for happiness, eudaimonia, comes from the word daimon, and implies, like the daimonion of Socrates, a god given state that we cannot manufacture or control. 
KNOWLEDGE OF THE PARTICULAR SITUATION

COMBINED WITH A VISION OF THE WHOLE

Our first axiom is focused on the discernment of reality. Our second axiom concerns the 'imaging' or visualising of peace. These two factors in benign change - knowledge of the particular and a vision of the whole - are interconnected.

In the Irish context, John Hume used to argue that a common factor connects the truth of the situation in Northern Ireland to the values underlying the European project. The big picture in Europe makes it easier to deal with the particular challenge in Northern Ireland. A local peace process can anticipate or reflect a broader trend. The whole is greater than the sum of its parts.

The principle that the 'micro' and the 'macro' can mirror one another has deep implications that go to the heart of our vision in this book: something that they have in common links all situations in which justice and hope are at stake. We have an urgent need, as the 21st century advances, to visualise a 'counterpart' at the global level to the processes we want to see happen in the Middle East, the Korean peninsula, the Indian subcontinent, and other situations of actual or potential conflict. In a culturally integrated world, a vacuum of values at the 'macro' level impacts on the prospects for peace in each individual context.

\section{GRADUALNESS}

In situations of conflict, we generally try to put in place a process that sets events on a new trajectory. In Northern Ireland, the Good Friday Agreement (Belfast Agreement) of $1998^{3}$ is the outcome of a peace process that lasted in one form or another for a quarter-century. The implementation of the Agreement over the last 20 and more years is also best understood as a process. 'Gradualness' of this kind belongs among the principles of benign change. Working to ensure that time is on our side is a key value in the context of our sixth and last axiom concerning the 'frameworks of engagement' that make multilateralism fit for purpose.

The gradual processes we have in mind are often open-ended. There are steps valid in themselves - intrinsically valid - whose precise consequences cannot be measured or foreseen. 
'A process, not the victory of a single point of view' - implicit in this common reading of the accommodation reached in Northern Ireland is that the anatomy of any benign transformation includes respect for difference. 'Parity of esteem' means more than coexistence; it is intended to lead to common action. 'Spilling our sweat' (the often repeated saying of John Hume) in the common interest brings a new perspective to questions of identity, ethos, and aspiration.

'Finding unity in the presence of difference' is a condition of both democratic politics and international negotiations. According to the traditions of liberal democracy, a government should be in a position to rely on the loyalty of the opposition ('Her Majesty's Loyal Opposition', as the British say). Diplomacy entails accepting the legitimacy of our negotiating partners. We are out, not to destroy the other side, but to build relationships and move forward together.

Achieving unity-in-difference reflects a truth about human nature. Virtue is outward-looking - not a matter of 'irreducible identity' so much as an acquired disposition to which we give expression when interacting with others. Unity of purpose does not eliminate differences; on the contrary, a culture of encounter sustained through time amounts in itself to unity of purpose. 'Unity in the presence of difference' better describes a functioning political compromise than the sophistic notion that a single product is being cleverly sold in different ways to different constituencies.

In the 21 st century, accelerating change often translates into a dangerous incapacity: we no longer seem to grasp that the encounter of different points of view, if conducted fairly, helps us journey together into the future and is, in itself, a form of solidarity. What needs to be recaptured is a sense of the intimate connection between respecting other people in their diversity and deepest humanity, preparing ourselves for dialogue and encounter, and gradually shaping a world characterised by an awareness of the oneness of humanity and the responsibility of each person to contribute to the collective well-being of the human race. The European Enlightenment looked forward to 'an age of reason'; the 'Axial Age' to which we look forward in this book is 'an age of sharing'. 


\section{CONSTRUCTIVE ENGAGEMENT WITH THE HOLDERS}

\section{OF POWER: A BIBLICAL REFLECTION}

The factors that accompany healing in a wounded social structure are clearly signposted in the Bible, including the need to engage constructively, or to be available to engage constructively, with those who hold power.

The movement initiated by two cousins - John the Baptist and Jesus - makes use of at least two key political concepts, 'assembly of the people' (ekklēsia) and 'choice of a common life' (koinōnia). This development of existing thought patterns changes the focus of our attention in significant ways.

You are Peter and on this Rock, I will build my ekklēsia.

(Matthew 16:18)

In Greek political thought, the term ekklessia is associated with 'popular' or people's power. Its use here can be taken to imply that change has many of its roots at the base of society. A new lifestyle and outlook among ordinary people, based on new forms of association, can transform the lived experience of those who persevere and suffer, and influence, over time, those who hold political, economic, and social power.

In the New Testament, that other Greek political term koinōnia, which we translate as 'the choice of a common life', is used to describe the shared life among followers of the new 'way':

If the shared life of the Spirit (koinōnia pneumatos) means anything ...

(Philippians 2:1)

If we live our lives in the light, as he is in the light, we have a shared life together (koinōnia).

(1 John 1:7)

In a passage to which we will return in Chapter 5, St Paul describes himself as the koinōnos of both the slave-owner Philemon and the slave Onesimus; he is 'in communion with' both (Letter to Philemon, verse 17).

Are John and Jesus thinking politically? The character of Roman governance is at issue throughout the gospel story, from the census at Bethlehem to the probing of Jesus on the taxation question to the executions on Golgotha. 
Jesus, following in the footsteps of the prophets, proclaims that the conglomerate of interests that dominates first century Palestine - the prevailing 'system' - should be questioned in the light of the 'kingdom of God'. To accept the baptism of John, means, among other things, to live and act in accordance with a social vision rooted in reality; it means attending to what is unattended to in the standard opinions of the time.

The Letter of James is written in Jerusalem not many years after the death of Jesus. 'James the Just' was respected in the community, as we see in Josephus $(2006,20.9)$, and he was a leader among the followers of the 'way' of Jesus. A strong political imagination echoes throughout the letter:

Be doers of the word (poietai logou, 1: 22) ... Pure, untainted religion in the eyes of God our Father is this: to watch over orphans and widows in their affliction. (1:27)

The author is scathing about status differences:

Now suppose a man comes into your synagogue, beautifully dressed and with a gold ring on, and at the same time, a poor man comes in in shabby clothes. (2:2)

To treat the rich and the poor differently is to contradict the 'law of freedom' (2:12), which demands that we judge the world (4:4) in the light of an independent God-given standard.

How, then, might we characterise the political imagination of John, Jesus, and James? Jesus states that 'the weightier part of the law is discernment, mercy, and faith' (Matthew 23:23).

Mercy (eleos) - 'our being moved by suffering' - draws us into a differently imagined social space. St Paul, in the passage from Philippians just quoted, identifies a 'deep-felt mercy' as a principal characteristic of those who embrace the new form of shared life. The gift of discernment (krisis) invites us to analyse the space that we share with others in terms of policy alternatives. Faith (Greek pistis; Latin, fides) is not altogether different to what Cicero means by 'good faith' - a willingness to trust in an unseen truth that may or may not be reflected in the civil law.

John and Jesus, like James, are careful not to mobilise politically against the Roman system; they are not oppositional (antitassomenoi) in the sense described in St Paul's Letter to the Romans (13:2). 
Nevertheless, we are informed (Mark 6:20) that Herod Antipas 'liked listening' to his prisoner John the Baptist. Pilate starts a dialogue with Jesus before being swept back into the Roman official's familiar world of political calculation. On the Areopagus and on several other occasions, St Paul explains his thinking in a public or official setting.

John is put to death for no clear legal reason, but as a favour to Herodias's daughter. Jesus is executed, not for an identifiable political offence, but apparently because claims he has made about his identity, and does not deny, are perceived by Pilate as somehow disorderly in themselves; a prefect had power to suppress dissent ('contumacy'), even where no crime had been committed. Josephus can see no legal basis for the execution of either John or James $(2006,18.116,20.9)$.

\section{FROM ANTIGONE TO KEN SARO-WIWA}

To breathe life into the ten factors of peaceful transformation, nothing is more important than the role of the courageous individual who perceives the underlying truth of situations and brings this to attention. Like Antigone, such individuals often lack the protection of established religious authorities. Like Antigone, they are often the victims of a legal rigmarole that is not law. To conclude the present chapter, we offer a contemporary case study. Ken Saro-Wiwa separated truth from falsehood and took a stand for justice in the face of seemingly invincible social forces.

\section{'LORD TAKE MY SOUL, BUT THE STRUGGLE CONTINUES': KEN SARO-WIWA AND THE OGONI CAUSE - BY CIARA JOYCE}

What motivates an individual to make the ultimate sacrifice to right a perceived injustice? To subject themselves to physical and personal hardships, to be separated from their family and friends and face financial ruin for the sake of others? The case of Ken SaroWiwa, the Nigerian writer and activist, and the Ogoni Nine is well known to those with an interest in human rights. On 10 November 1995, Saro-Wiwa and eight of his colleagues were executed by the 
Nigerian government. The crime they were found guilty of was incitement to murder. Brought before a military tribunal during the dictatorship of Sani Abacha, the trial was a farce and a guilty verdict was predetermined.

Ogoni, one of the River States on the coast of Nigeria and home to a population of over half a million people, came to international attention following the campaign to save it from environmental devastation due to the extraction of oil by Royal Dutch Shell. Despite the huge profits made by Shell and the Nigerian Government from the oil rich Niger Delta, Ogoni lacked basic facilities, such as running water and reliable electricity. Pollution caused by the oil industry had a devastating effect on a community dependent on fishing and farming for its livelihood. It also had a negative impact on the health of the community.

In 1990, Saro-Wiwa established the Movement for the Survival of the Ogoni People (MOSOP) and began a peaceful campaign to highlight these issues and bring Shell to account for the damage caused. Although they led a non-violent campaign for change, SaroWiwa and his colleagues were arrested in May 1994. Four Ogoni chiefs were murdered during a night of violence in the region, and the MOSOP activists were charged with 'procuring and inciting' others to murder. Despite an international campaign to save their lives, including a Nobel Peace Prize nomination for Saro-Wiwa, the Ogoni Nine were executed.

Saro-Wiwa was a successful businessman, a writer of novels, poetry, and children's books. A complex individual, he was a man of conscience, charismatic and contradictory, and described as generous to a fault by his eldest son, Ken Wiwa (2000, p. 21). An agnostic for most of his adult life, Saro-Wiwa's motivation seems to come from a deep loyalty to his people - the Ogoni; all his personal success, he maintained, was for them. Compelled by a belief in justice and human rights for a people he knew had been deeply wronged, he put his personal resources and his own freedom to the forefront in order to free the Ogoni - the people and land, which he believed to be one - from continued exploitation and destruction. There was no personal gain for Saro-Wiwa, apart from the peace of mind that resulted from yielding to his sense of duty and seeing the growth of a movement he founded. 
We are fortunate that, as a prolific writer, Saro-Wiwa captured his thoughts and aspirations for the Ogoni on paper. During his time in military detention Saro-Wiwa corresponded widely, including with an Irish nun, Sister Majella McCarron, who is a member of the Missionary Sisters of Our Lady of the Apostles (OLA). His letters were smuggled out of military detention in breadbaskets and donated to Maynooth University library in 2011. From his letters and his writing, Saro-Wiwa could only be described as a man devoted to the Ogoni - people, landscape and culture - and as a man resigned to his fate. In December 1994, he wrote to his son Ken Wiwa: 'I am a protector of the Ogoni' (Wiwa, 2000, p. 167). Ken Wiwa also felt that it pained his father that an area like Ogoni, rich in resources, was one of the 'poorest corners of Africa' (Wiwa, 2000, p. 81).

During his confinement, Saro-Wiwa found comfort in reading both the Bible and the Quran. Ken Wiwa described him as 'at peace with himself' (Wiwa, 2000, p. 211). In his letters to Sister Majella, Saro-Wiwa expresses his hopes for the Ogoni and the future of the campaign, while reflecting on the possible outcome of his incarceration. On 13 July 1994, he writes,

there are a lot more difficulties ahead. However, I believe that I've done what God wanted me to, and have spared nothing to achieve his will. He will have to decide what happens to me. Incarceration is nothing. I must expect more of it, and even death. But I do want to live to help re-create Ogoni society.

(Archive, PP/7/3)

On 21 March 1995, he writes,

I have never really felt I was in danger. The sure knowledge of my innocence gave me that feeling. I thought that l'd remain in captivity until God should have used that fact to make the Ogoni cause better known and pave the way for solving some of the many problems which confront the Ogoni people and similar groups in Nigeria, if not the African continent. Big thought. Big assignment.

(Archive, PP/7/23)

Saro-Wiwa is probably best understood by the words of the final statement he prepared but was prevented from reading at his trial: 
I am a man of peace, of ideas. Appalled by the denigrating poverty of my people who live on a richly endowed land, distressed by their political marginalization and economic strangulation, angered by the devastation of their land, their ultimate heritage, anxious to preserve their right to life and to a decent living, and determined to usher to this country as a whole a fair and just democratic system which protects everyone and every ethnic group and gives us all a valid claim to human civilization, I have devoted my intellectual and material resources, my very life, to a cause in which I have total belief and from which I cannot be blackmailed or intimidated ... I call upon the Ogoni people, the peoples of the Niger Delta, and the oppressed ethnic minorities of Nigeria to stand up now and fight fearlessly and peacefully for their rights. History is on their side. God is on their side.

(Saro-Wiwa, 2005, p. 193)

With a clear mind and conscience, Saro-Wiwa appears to have kept his dedication and his focus until the very end. His reputed last words at the gallows, spoken in his native Khana, were 'Lord take my soul, but the struggle continues' (Wiwa, 2000, p. 218).

\section{NOTES}

I theōn t'enorkon dikān-our translation.

2 III.82.4, III.82.6, III.82.8, III.84.2, III.84.3 - our translations.

3 Department of Foreign Affairs and Trade. (2018). The Good Friday agreement and today. www.dfa.ie/our-role-policies/northern-ireland/ the-good-friday-agreement-and-today/.

\section{REFERENCES}

Baumgarth,W., and Regan, R. (eds.). (1988). St. Thomas Aquinas on Law, Morality, and Politics. Cambridge: Hackett Publishing Company.

Chan, J. (20I4). Confucian Perfectionism: A Political Philosophy for Modern Times. Princeton and Oxford: Princeton University Press.

Clark, C. (2013). The Sleepwalkers: How Europe Went to War in 1914. London: Penguin Books.

Dostoevsky, F. (2000). Crime and Punishment, translated by C. Garnett, Ware: Wordsworth Editions.

Dostoevsky, F. (2003). The Brothers Karamazov, translated with and introduction and notes by D. McDuff (revised edition). London: Penguin Books. 
Dostoevsky, F. (2004). The Idiot, translated with notes by D. McDuff. London: Penguin Books.

Dostoevsky, F. (2008). Demons, translated by R.A. Maguire. London: Penguin Books.

Finley, M. (I980). Ancient Slavery and Modern Ideology. London: Chatto and Windus.

Garnsey, P. (1996). Ideas of Slavery from Aristotle to Angustine. Cambridge: Cambridge University Press.

Ghosh, A. (2016). The Great Derangement. Gurgaon: Allen Lane.

Griffin, M. (1976). Seneca: A Philosopher in Politics. Oxford: Oxford University Press.

Hopkins, G.M. (2005). 'God's Grandeur', in A.M. Eastman et al. (eds.), The Norton Anthology of Poetry, 5th edn., pp. 887-888. New York: W.W. Norton and Company.

Jonas, H. (1984). The Imperative of Responsibility: In Search of an Ethics for the Technological Age. Chicago: University of Chicago Press.

Josephus. (2006). Jewish Antiquities, translated by W. Whiston. Ware: Wordsworth Editions. (Whiston's translation was first published in I737)

Ken Saro-Wiwa Archive, Maynooth University Library. PP/7/3. The letters written by Saro-Wiwa to Sister Majella McCarron are available for consultation at Maynooth University Library.

Levy, H. (I97I). Translations from Po-Chü-I's Collected Works. New York: Paragon Book Reprint Corp.

Plutarch. (r9i6). Pericles and Fabius Maximus, Nicias and Crassus, translated by B. Perrin. Loeb Classical Library. Cambridge: Harvard University Press.

Pushkin, A.S. (I954). The Captain's Daughter, translated by Ivy and T. Litvinov. Moscow: Foreign Languages Publishing House (first published in Russian in 1836$)$.

Pushkin, A.S. (2008). 'Untitled Poem,' in I.G. Irskaya and Y.G. Fridstein (eds.), Alexander Pushkin: In Hopes of Fame and Bliss to Come. Moscow: Bagrius (bilingual edition of Pushkin's selected poems).

Saro-Wiwa, K. (2005). A Month and a Day and Letters. Banbury, Oxford: Ayebia Clarke Publishing.

Seneca. (I935). Moral Essays, Volume III (De Beneficiis), translated by J.W. Basore. Loeb Classical Library. Cambridge: Harvard University Press.

Shelley, P. (2003a). 'A Defence of Poetry', in Z. Leader and M. O'Neill (eds.), Percy Bysshe Shelley: The Major Works, pp. 674-701. Oxford: Oxford University Press.

Shelley, P. (2003b). 'A Philosophical View of Reform', in Z. Leader and M. O'Neill (eds.), Percy Bysshe Shelley: The Major Works, pp. 636-674. Oxford: Oxford University Press. 
Shelley, P. (2003c). 'The Mask of Anarchy', in Z. Leader and M. O’Neill (eds.), Percy Bysshe Shelley: The Major Works. Oxford: Oxford University Press.

Sophocles. (1987). Antigone, edited with translation and notes by A. Brown. Warminster: Aris and Phillips.

Thucydides. (1996). The Landmark Thucydides: A Comprehensive Guide to the Peloponnesian War (revised edition of the Richard Crawley translation), edited by R.B. Strassler. New York: Free Press.

Wiwa, K. (2000). In the Shadow of a Saint. London: Doubleday.

Yeats, W. (I994). 'To a Shade', in B. Kiely (ed.), Yeats' Ireland: An Illustrated Anthology. London: Tiger Books International. 